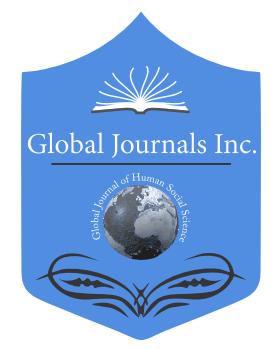

\title{
Translatability of Metaphors in the Dubbing of Animation Songs from English into the Egyptian Dialect
}

By Maysa' Musleh Tahseen Musleh

Arab American University-Palestine

Abstract- This research paper examined the ways how translators translated metaphors in the dubbing of animation songs and measured the degree of loss occurred in rendering metaphors from English into Arabic; these two languages are culturally and linguistically distinct languages. This study employed descriptive qualitative methods. The data used in this research were metaphors of songs from three animated musical movies: Beauty and the Beast, Tangled, and Pocahontas. This paper analyzed the translation of metaphors depending on the cognitive theory proposed by Mandelblit (1995). The results proved that even though translating metaphors in animation songs was a laborious process, they did not always cause a problem of untranslatability; on the contrary, translators can render metaphors from English onto Arabic without a significant loss in terms of meaning and sound patterns. Compensation in kind and compensation in place helped to achieve the translatability of metaphors in cartoon films' songs. The analysis of source and target metaphors revealed that there were three translation procedures used to translate metaphors in animation songs, namely: replacing the source metaphor with a target metaphor (substitution), translating the metaphor into sense (paraphrasing), and using literal translation.

Keywords: cognitive approach, metaphor, animation, alliteration, dubbing, compensation.

GJHSS-G Classification: FOR Code: 200399

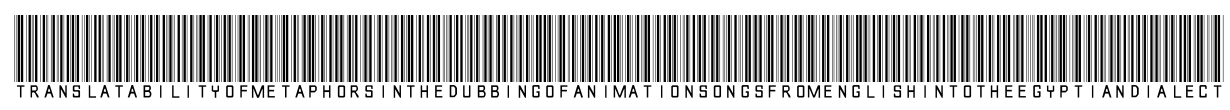

Strictly as per the compliance and regulations of:

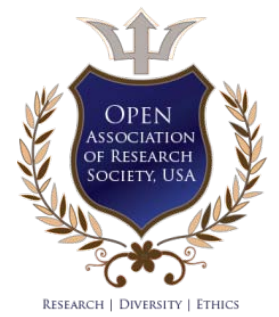

(C) 2020. Maysa' Musleh Tahseen Musleh. This is a research/review paper, distributed under the terms of the Creative Commons Attribution-Noncommercial 3.0 Unported License http://creativecommons.org/licenses/by-nc/3.0/), permitting all non-commercial use, distribution, and reproduction in any medium, provided the original work is properly cited. 


\title{
Translatability of Metaphors in the Dubbing of Animation Songs from English into the Egyptian Dialect
}

\author{
Maysa' Musleh Tahseen Musleh
}

\begin{abstract}
This research paper examined the ways how translators translated metaphors in the dubbing of animation songs and measured the degree of loss occurred in rendering metaphors from English into Arabic; these two languages are culturally and linguistically distinct languages. This study employed descriptive qualitative methods. The data used in this research were metaphors of songs from three animated musical movies: Beauty and the Beast, Tangled, and Pocahontas. This paper analyzed the translation of metaphors depending on the cognitive theory proposed by Mandelblit (1995). The results proved that even though translating metaphors in animation songs was a laborious process, they did not always cause a problem of untranslatability; on the contrary, translators can render metaphors from English onto Arabic without a significant loss in terms of meaning and sound patterns. Compensation in kind and compensation in place helped to achieve the translatability of metaphors in cartoon films' songs. The analysis of source and target metaphors revealed that there were three translation procedures used to translate metaphors in animation songs, namely: replacing the source metaphor with a target metaphor (substitution), translating the metaphor into sense (paraphrasing), and using literal translation.

Keywords: cognitive approach, metaphor, animation, alliteration, dubbing, compensation.
\end{abstract}

\section{INTRODUCTION}

A nimation is the creation of a cartoon film using technological improvement. In this audiovisual film, a story is being portrayed in a way that is attractive for a young audience. For this reason, there are many songs in most of the animation films, and these songs make the dubbing of an animation a challenge. Dubbing involves replacing a source language (SL) voice with a target language $(\mathrm{TL})$ one. Thus, the translator is surrounded by many factors that should be considered in the process of dubbing animation songs. These are the content of the source song (SS), the gap between the source and target cultures, the audience, lip synchronization, music, and sound patterns, such as phonic and prosodic features.

The difficulty of dubbing animation songs increases, even more, when these songs include metaphors. When metaphors are used, we approach the problem of untranslatability because a metaphor is an expression that is not used literally; instead, it expresses meaning in an indirect, implicit, and creative way.

Therefore, it is a priority that translators understand the intended meaning of this indirect comparison before rendering it into the TL. When translators make sure that the sense is intact, they have to pay attention to the musical features of the song, which contribute to the complexity of translating metaphors in dubbed animation songs.

\section{Purpose of the Study}

This study aims at covering issues related to the translation of metaphors in dubbed animation songs, particularly when these metaphors are used for sound effects. The challenges translators face, and the ways they resolve them are discussed. The quality of the outcome is, moreover, among the main issues to be dealt with in this research paper. This study tests the translatability of metaphors in dubbed animation songs; examines whether the cultural gap is bridgeable; identifies the translation procedures used in translating metaphors in dubbed animation songs, and determines where and when translating a metaphor in dubbed animation songs meets with and differs from translating a metaphor in other literary texts.

\section{ili. Statement of the Problem}

This study deals with the complexity of translating metaphors in the dubbing of animation songs. The metaphors are at risk of being misunderstood and then misinterpreted because of the cultural and linguistic differences between English and Arabic. What sophisticates this process is, furthermore, the sound patterns that a metaphor may have.

Author: English Language Centre, Arab American University-Palestine. e-mail: maysa.musleh@aaup.edu 


\section{IMPORTANCE OF THE STUDY}

Although there is a great amount of research on the translation of metaphors, there is not enough attention paid to translating metaphors in animation and particularly in animation songs. The researcher was not able to find researches in this field of study. Hence, the researcher expects that this research paper will motivate researchers to investigate and study this issue in more detail.

\section{The Hypothesis of The Study}

This study depends on the cognitive theory of metaphor translation to examine the translation of metaphors. It concerns how people conceptualize the world around them and how this is reflected by using words. Subsequently, this study tests the assumption that loss in translating metaphors of animation songs is unavoidable. This study claims that in handling metaphors in the dubbing of animation songs, translators can preserve both content and sound patterns.

\section{Review of Related Literature}

\section{a) Metaphor and Translation}

This section is more limited than it is expected to be because this field of study, where the theory of translating animation songs and the theory of translating metaphors are combined, has not received much attention.

One of the extensive studies on translating metaphors is conducted by Newmark (1988). He defines metaphors as figurative cognitive, aesthetic expressions that describe one thing in terms of another, demonstrating resemblance between these different things: the image and the object. Newmark (1995, P104-105) uses these two terms (the image and object) and the sense to describe metaphors. The image is the picture the metaphor draws in peoples' minds, the object is what the metaphor describes, and the similarity between the object and the image is the sense which also reflects the meaning intended by the metaphor.

He further suggests seven procedures to deal with metaphors in the process of translation. These can be summarized as follows: 1 . Reduce the metaphor into its sense, 2. reproduce the same image in the TL, 3. convert the metaphor into a simile, 4. translate the metaphor into a simile along with its sense, 5 . translate it by an equivalent metaphor in the TL, 6. combine the same metaphor with its sense and 7. delete the metaphor. Newmark adds that in dealing with metaphors, the contextual factors take supreme over the importance of the metaphor in the text (Newmark, 1988).

Dickens et al. (2002), additionally, name five approaches to tackle the translation of metaphors, namely: literal translation, transplanting the source language metaphor (SLM) with an equivalent target-language metaphor, paraphrasing the metaphor, converting the metaphor to a simile and deleting the metaphor altogether. Our view is that every single one of these methods affects the content, lyrical style, and sound patterns differently.

Many scholars, such as Hatim and Munday (2004), Luthen (2002), Nida and Taber (1969) and Speath (1915) state that when form and meaning are interrelated, we approach untranslatability.; therefore, they suggest that text arrangement or interpretation are the terms that have to be used in the process of transferring song lyrics from one language into another. In their paper 'TRANSLATING SONG LYRICS A Study of the Translation of the Three Musicals', Andersson and Ulvaeus (2009) claim that paraphrasing is the dominant translation strategy followed in translating song lyrics.

Henceforth, when it comes to translating metaphors in a song, the complexity of translation is even elevated, and loss is unavoidable.

\section{b) Metaphor Translation in Literary Texts: The Faithful versus the Beautiful}

In literary texts, metaphors are not as easily accessible and familiar as they are in other genres. Translating metaphors in literary texts is a pivotal issue that attracted translation theorist's attention. Translation scholars have discussed how metaphors can be translated in stories, poems, and other expressive literary texts.

In translating metaphors in stories, for example, both form and meaning are of paramount importance. However, more often than not, the priority is given to transferring the sense, not to the story's form. Readability is identified as one crucial criterion in translating stories. Thus, translators' resort to the communicative translation where the semantic translation is not of much help (Park, 2009).

Unlike translating metaphors in stories, the form is not compromised in translating metaphors in poetry. On the contrary, the form and meaning of metaphors are equally important as it is exactly the case with translating metaphors in dubbed animation songs. What distinguishes the translation of metaphors in animation songs from metaphor translation in poems is that animation songs are combined with music. In addition to the rhyme, rhythm 
and meter that have to be considered in translating poems, music is a crucial component in dubbed animation songs. Simplification is another useful criterion that has to be considered since the audience is young teenagers. However, in translating serious poems or Shakespearean work, translators do not think about simplicity since the focus is on creating an equally creative and aesthetic text.

In high literature, not only form and meaning have to be preserved; the image in the TL metaphor has also to be as close as possible to that of the SLM. In other words, the metaphor has to be kept in translation (ibid.). In the dubbing of animation songs, on the other hand, if the image of the source metaphor (SM) is very sophisticated for the young audience, and if keeping the metaphor affects the sound patterns of the song, translators are not expected to keep the metaphor or its image.

Another difference between metaphors in animation songs and metaphors in other literary texts is the function a metaphor has. For example, in creative writing, such as poetry and creative prose, metaphors have aesthetic value. These metaphors have to be interpreted literally. Unlike serious creative literature, decorative metaphors are used in other literary texts, such as fiction and essays. Decorative metaphors can be replaced by other metaphorical or non- metaphorical expressions (Raymond van den Broeck, 1981, P76). Metaphors in animation songs are of the decorative, not the creative type. For example, the metaphors: 'I'm a question to the world,' 'let it roll right off your shoulders,' and 'there is a perfect world shinning in your eyes' are all instances of decorative metaphors.

Low (2017) states that translators have to preserve the richness of metaphors in translating song lyrics. However, this is not the aim of translators who deal with animation song metaphors.

It is worth mentioning that translators of animation songs have to produce a simplified, sing-able, and acceptable metaphor that is faithful to the SM. This research paper will demonstrate when and how this is achievable.

\section{Vil. Methodology}

The data was collected from animation songs dubbed into Arabic, and particularly into the Egyptian Dialect (ED). In this study, there are about forty-four metaphors taken from the songs of three animated musical films: 'Beauty and the Beast,' 'Tangled,' and 'Pocahontas.' Nineteen of these metaphors are translated into ground. Fourteen are translated literally. Eleven metaphors are translated into equivalent Arabic metaphors (EAM).

The ED version of the animation 'Tangled' was retrieved from https://shahidwbas.com/watch.php?vid $=222 \mathrm{e} 0297 \mathrm{~b}$ (on the $5^{\text {th }}$ Jan 2020), and the English version retrieved from https://www.youtube.com/ watch? $v=$ geZ84BoqHv4 (on $3^{\text {rd }}$ Jan 2020). The English version of 'Beauty and the Beast' was retrieved from https://www.youtube.com/watch?v=bur4cVtXo4c. (on 10 $10^{\text {th }}$ Jan 2020). Two days later, the Arabic version retrieved from https://vod.alarab.com/v75328\%D9\%81\%D9\%8A\%D9\%84\%D9\%85_\%D8\%A7\%D9\%84\%D8\%A7\%D9\%86\%D 9\%8A\%D9\%85\%D9\%8A\%D8\%B4\%D9\%86_\%D8\%A7\%D9\%84\%D8\%AC\%D9\%85\%D9\%8A\%D9\%84\%D8\%A9_\%D9\% 88\%D8\%A7\%D9\%84\%D9\%88\%D8\%AD\%D8\%B4_1991. 'Pocahontas' was retrieved from https://yesmovies.ag/ movie/pocahontas-7511/watching. html (on $7^{\text {th }}$ Jan 2020), and its dubbing retrieved from https://www.stardima. com/watch/\%D9\%81\%D9\%8A\% D9\%84\%D9\%85\%D9\%83\%D8\%B1\%D8\%AA\%D9\%88\%D9\%86\%D8\%A8\% D9\%88\% D9\%83\%D8\%A7\%D9\%87\%D9\%88\%D9\%86\%D8\%AA\%D8\%A7\%D8\%B3-pocahontas-1-\%D9\%85\%D8\%AF\%D8\%A 8\%D9\%84\%D8\%AC-\%D9\% 84\%D9\%87\%D8\%AC\%D8\%A9-\%D9\%85\% D8\%B5_0ac 566e12.html (on 9 $9^{\text {th }}$ Jan 2020). These three animations are translated by Disney Character Voices International, INC.

This research is a qualitative study that uses the descriptive-analytic approach to analyze the data. The researcher additionally evaluated the collected data according to the following criteria: naturalness, acceptability, accuracy, fluency, simplicity, musicality, and sound patterns: rhyme and alliteration.

In this study, the researcher has classified metaphors according to the translation strategy used in translating metaphors in dubbed animation songs. The first section focuses on the metaphors that are translated into EAMs. The second section analyzes the metaphors that are translated into the ground level. In the third section, the literal translation strategy is discussed. In the first and second sections, two SMs are analyzed then their dubbing into the ED is investigated to examine the degree of loss in terms of meaning and sound patterns. The last section presents examples of metaphors that are translated literally.

\section{Results}

The results of this study can be summarized as follows:

In the dubbing of animation songs, there were three methods followed to handle metaphors: 1) replacing the SLM with a target language metaphor (TLM), 2) reducing the metaphor into its sense, and 3) using literal translation procedure. 
It was clear that translating a metaphor into a TLM was not a priority. Yet, it was advisable as the EAM not only approximated the meaning of the SM, but it also functioned as a decorative tool. It also created a more entertaining song and enriched the imagination of young audience.

However, the EAM had to be: 1) comprehensible for a young audience, 2) commonly used in their culture, 3) suitable for the sound patterns of the original song, and 4) close in meaning to the SM. Furthermore, it was, obviously, possible to reflect the same image of the target metaphor (TM) through compensation in kind (CIK) and compensation in place (CIP).

Cultural transposition and partial equivalence were the procedures followed in replacing the SLMs with TLMs. The translator cleansed the dubbed target song (DTS) from all foreign items and ideas and replaced them with culture-specific Arabic metaphors.

There were two results of this cultural transplantation: 1) partial transplantation where the image and vehicle of the SM were kept, 2) total transplantation where the image and vehicle of the SM were transformed.

Preserving the image and vehicle was not of priority in translating metaphors in animation songs; meanwhile, maintaining the sense and sound patterns was of supreme importance. Consequently, the translator resorted to translating the metaphor into the ground level and using the literal translation strategy, when it was impossible to render the SM into a TM.

In animation songs, the vehicle of a metaphor was handled differently. It depended on whether the same vehicle existed in the TL and had the same function as the SL vehicle or not.

In translating a metaphor into ground (paraphrasing), dynamic equivalence was aimed at, as the purpose of translation was to create an equivalent effect on the target audience. Moreover, making the implicit explicit was another adjustment technique used in translating metaphors in animation songs.

It was also clear that literal translation was a successful way of translating metaphors in animation songs, in case it produced approximate sound patterns and natural, acceptable, and comprehensible meaning for young teenagers. In some instances, where literal translation was not enough to preserve the rhyme of the song, the translator resorted to adding a word or phrase that helped to produce the required rhyme without affecting the meaning and syllable count of the verse.

The audience, target culture, and sound patterns, particularly alliteration and rhyme, were crucial factors determining which translation procedure to be followed in translating a metaphor in an animation song.

If the metaphor had a sound pattern and this sound pattern had a function in the song, this sound pattern had to be kept or approximated in the DTS.

In dealing with metaphors in the dubbing of animation songs, the translator did not sacrifice the meaning for the sake of sound effects nor the sound effects for the sake of the sense; on the contrary, by taking the contextual factors and text type into consideration and by using the linguistic repertoire of Arabic language and culture, the translator was successful in the translation process. What also helped to make this translation successful was using compensation: CIK and CIP.

The criteria that the translator worked accordingly were: accuracy of the message, faithfulness to the intended content of the SM, sincerity to the target culture, as well as, acceptability, naturalness, and musicality.

Despite the complexity of translating metaphors, it was possible to render the intended meaning of the SMs preserving the sound patterns when dubbing animation songs from English into Arabic and, more specifically, into the ED. It was also clear that instances of gain were detected. The DTSs were sometimes clearer for the young audience.

Using the Egyptian dialect gave dubbing flexibility as it offered a wide range of options for translators to choose the option that: 1) reflected the meaning of the SM and 2) fitted its sound patterns.

This research paper was proof that metaphors in animation songs were translatable, despite all the challenges the translator faced starting from understanding the intended meaning of the SM to approximating its sound patterns. This study also proved that the cultural gap between English and Arabic could be bridgeable.

The TMs were easy to be comprehended. Translators were able to produce clean metaphors that do not have cultural, contextual, or stylistic peculiarities.

The translation of metaphors in animation songs should be beautiful and faithful at the same time as in poetry. Neither the meaning nor the form has to be sacrificed. What distinguishes translating metaphors in animation songs from translating metaphors in poetry are: simplification and approximating the sound patterns of the SSs.

\section{Discussion}

\section{a) English Culture-Specific Metaphors Translated into EAMs}

This section will measure the degree of loss, in terms of meaning and sound patterns, in translating SMs into TMs. The following table presents the SMs that are translated into TMs. The researcher studies two of these metaphors. 
Table 1: SLMs translated into TLMs

\begin{tabular}{|c|c|}
\hline SMs & TMs \\
\hline Gaston, you have to pull yourself together & لازم تتخلب ع محنتك \\
\hline Looking so down in the dumps & لو أشوف مناخيرك ف الأرض \\
\hline Set to sacrifice our children to his monstrous appetite & يتعشى الوحش بأطفالنا.. كرشو دا ترمح فيه الخيل \\
\hline And I won't be so huge & و وأرجع وسطي محبوك \\
\hline Why, I'll easily fit through that door & بشبه وسط المنكانمش ديناصور \\
\hline Still a little sapling just a sprout & لسة عودلك اخضر ور هيفة \\
\hline $\begin{array}{c}\text { All those days chasing down a day dream } \\
\text { All those years living in the blur }\end{array}$ & طجرل العمر عائشة ف أحلامي \\
\hline $\begin{array}{l}\text { I'm malicious mean and scary } \\
\text { My sneer could curdle dairy }\end{array}$ & في أناوشين أطران الخميرةة \\
\hline Singing to the cedar flute & اطلع من البيضة يكتكوت \\
\hline
\end{tabular}

'Still a Little Sapling Just a Sprout'

In the song 'Mother Knows Best' in the animation film 'Tangled,' the woman who pretends to be Rapunzel's mother is trying to convince Rapunzel that she is weak and unable to protect herself. In this way, she will be able to persuade Rapunzel to stay in the tower. To convey her message, the woman uses a metaphor and a simile at the beginning of the song. She says: 'look at you as fragile as a flower, still a little sapling just a sprout.'

The parts of the metaphor 'still a little sapling just a sprout' are the object (Rapunzel), the vehicles (sapling and sprout), and the sense (being young and weak). One domain- source or donor- is partially mapped into another domain- target or recipient (Barcelona, 2000, P3). The source domain (SD) is Rapunzel- which is itself a sub-domain of human beings. This domain is mapped into the target domain (TD): a plant- a sprout and a sapling, which are sub-domain of a plant. The similarity between a plant and Rapunzel is as follows:

$>$ The small plant is young and green; Rapunzel is beautiful and young.

$>$ The young plant and the young person need someone to protect them.

$>$ The young plant has to be kept in a place where nothing harms it, and Rapunzel has to live in the tower to be protected from other people.

$>$ The sprout is the shoot of a plant that stays under the soil; Rapunzel also has to stay in the tower.

$>$ These similarities between the SD and TD have to be reflected in the translation of this metaphor.

The EAM: لسة عودك أحضر ورهيفة'

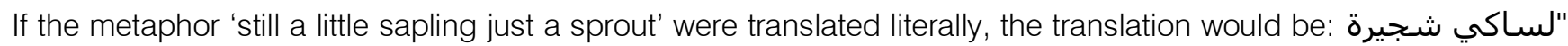

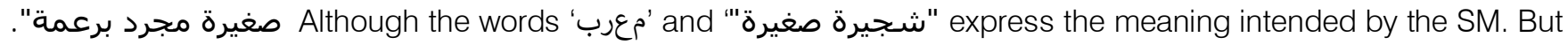

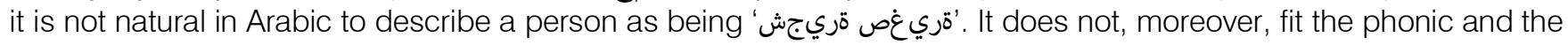
prosodic features of the SS.

This metaphor, instead, is translated as: "لسة عودك أخضر ورهيفة "In the Arab culture, the metaphor: 'رضخأ كدوع is used to indicate that the person is young, has no experience in life, and is unable to protect him/herself. This meaning is further enforced by the word رهيفة, which means kind and fragile. But, is there any loss incurred on the levels of meaning and sound patterns?

\section{Loss in Meaning}

The SM does not only mean that the person is young and weak; it also indicates that this person has to be hidden inside the tower. This meaning is implied by the word 'sprout.' The point that Rapunzel has to live in the tower is crucial in this animated movie. The EAM does not reflect this sense. However, it is expressed in the following line when the woman says "عشان فوء في أمان كتير". The meaning of 'sprout' is compensated for in another place in the stanza; this is called compensation in place (CIP).

The vehicle or the TD is the same in the SM and the TM. In both languages, Rapunzel is compared to a plant. In English, the sprout and sapling are used, whereas the branch is used in Arabic. The same domain is referred to, but different sub-domains are used. CIK is used to preserve the intended meaning.

But, why does not the translator use the same sub-domain 'بر عمك أخضر' instead of ' برودك أخضر'? The word 'sprout' is, nevertheless, used in Arabic to describe a young person, and it also implies that this person is rooted in a place. The reason why the translator uses ' عودك اخضر' is that it is more in circulation. Here, as the audience is young, they hear a familiar term that helps them to understand the meaning. The color green is used in this context because this color is an indication of being young. Another reason for using "عودك أخضر not "برعمك"برعمك أخضر" is to avoid loss in sound patterns. 
Loss in Sound Patterns

Table 2: The first stanza from the song 'Mother Knows Best' and its ED dubbing

\begin{tabular}{|c|c|}
\hline SS & DTS \\
\hline Look at you as fragile as flower. & مش معئول انت وردايةوهشه \\
\hline Still a little sapling just a sprout. & لسة عودك أخضر ور هيفية \\
\hline You know why we stay up in this tower & انت عارفة ليه في البرج ده عايشث \\
\hline Rapunzel: "I know but" & عارفة بس... حئوللك \\
\hline That's right to keep you safe and sound dear & عثان فوء في امان كتيير \\
\hline Guess I always knew this day was coming & تئلب حس انك فيوم حتنولي \\
\hline Knew that soon you'd want to leave the nest. & عايزا اسيب الثق أصل زهئت \\
\hline Soon but not yet & كل شيء بوئت \\
\hline
\end{tabular}

There is alliteration, the repetition of sound or sounds at the beginning of the words, 'still, sapling, sprout, stay, safe, sound and soon.' The function of this alliteration is to connect these words to create cohesion and coherence in the stanza. This alliteration means that Rapunzel is still a sprout and sapling, so she has to stay in this tower to be safe and sound.

In the DTS, alliteration is found in: "عودك وغارف و عايشة و عايزة و عش". This alliteration indicates that

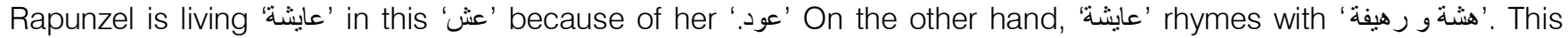
rhyme implies that she is living in this tower because she is fragile. The meaning reflected by the alliteration in the SS

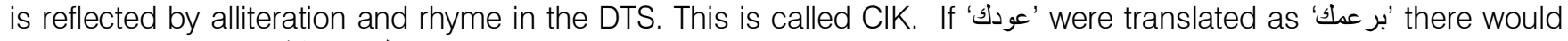
not be alliteration in 'عودك و عايثن' and the meaning expressed by this alliteration would be lost.

'My Sneer Could Curdle Dairy'

'أناو شي نطع الخميرة // في عجين افران كتيرة ' is a translation for 'I'm malicious, mean, and scary// My sneer could curdle dairy.' 'My sneer could curdle dairy' is a metaphor used in a song called 'l've got a dream.' In this song, Rapunzel met many ugly people who sang this song. This metaphor means that the speaker is ugly and scary to the extent that his derisive smile curdles dairy. 'Curdle,' as is defined in Al-maany dictionary, means: become thicker and more solid as it dries ("Curdle," 2020). The word curdle is used with words, such as milk and blood. If one's blood is curdled, it is frozen in the veins. The sense that the speaker wants to express is that he is a scary ugly person whose smile freezes the blood of other people. In this metaphor, the object is (sneer), the vehicle is (curdle), and the sense is (ugliness that frightens people).

In translating this metaphor, the translator has to be aware that in Arabic, we do not use the image of curdling milk to describe an ugly person. However, we can do so by the metaphor: . "وش بيئطع الخميرة من البيت A complete transformation happens. Neither the same vehicle nor the same image is used. The object in the Arabic metaphor is 'وش'; بيئطع الخميرة' ' the vehicle is the sense is (ugliness and bad luck). The translator adapts the English metaphor to fit the Arab culture. This cultural transplantation happens to add a native color to the animation song (Mnacere, 1988, P569). In doing this, the translator minimizes the effort on the part of the young audience.

Loss in Meaning

Table 3: The first stanza from the song 'l've got a dream' and its ED dubbing

\begin{tabular}{|c|c|}
\hline SS & TS \\
\hline I'm malicious, mean, and scary & أنا وشي نطع الخميرة \\
\hline My sneer could curdle dairy & في عجين أفران كتيرة \\
\hline And violence-wise & وبتاع اجر ام في \\
\hline My hands are not the cleanest & في حالة الفبرقة \\
\hline But despite my evil look & ميغر كيثداو الوش \\
\hline And my temper and my hook & و الناس الي بتكش \\
\hline
\end{tabular}

This Arabic metaphor means that this person is scary, ugly, and brings bad luck so that no yeast will be available for dough. The sense of bad luck is not implied in the SM; this is considered an addition to the meaning, so it is a loss. The image of curdling milk, freezing blood, and a scary voice is not expressed in the Arabic metaphor; this is another loss. But, do these instances of loss affect the meaning? 
It is not natural to translate this metaphor literally ' بتسامتي الساخرة نخثر اللبن 'The exact image, therefore, is compromised for naturalness and comprehensibility. Preserving the image and vehicle is not a priority in translating metaphors in animation songs. Maintaining the sense and sound patterns is the point.

The meaning of the three-word list 'malicious, mean, and scary' seems to be lost in the translation. The words 'خسيس و خبيث'are not expressed by the metaphor. However, this meaning is reflected in another part in this stanza 'خبتاع اجر ام' which implies being خسيس وخبيث. CIP is used to minimize the loss in meaning. Whether the deletion of these three words affect the musicality of the song or not is the focus of the following section.

\section{Loss in Sound Patterns}

If the translator translated 'I'm malicious, mean and scary' as 'انا خبيث وخسيس و مخيف' and then translated the metaphor into 'وشي ئطع الخميرة'there would not be any loss in the meaning, but the rhyme and the rhythm of the song will be broken; nevertheless, the three words alliterate with each other.

In this stanza, there is alliteration in 'malicious, mean// scary, sneer// could, curdle.' There is also rhyme in

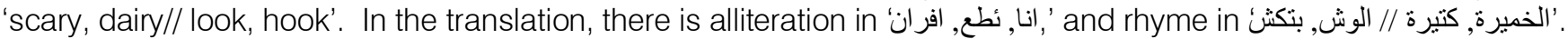
The two sets of alliteration in the first two English lines are also expressed by alliteration in the Arabic Metaphor. The rhyme of the SS is preserved. Consequently, there is no loss in sound patterns.

It is noted that by using the Arabic repertoire, the translator succeeds in achieving this aim. He uses the word البيت instead of preserve the alliteration and syllable count. He also adds the wordthe end of this verse to keep the rhyme of the stanza.

Transplanting the SLMs with EAMs doesn't result in any significant loss on meaning or sound levels.

\section{b) The Metaphor is Reduced into its Sense}

Farghal says that "metaphors rarely correspond formally and/or functionally across languages," so the metaphor is to "be reduced to its communicative import" (Farghal, 1995, P56). Thus, translators often translate a metaphor into its sense.

Table 4: Metaphors translated into the ground level

\begin{tabular}{|c|c|}
\hline SMs & TMs \\
\hline For there is no man in town half as manly perfect, a pure paragon! & مين في بلدنا يا جدعان زيو فتوة \\
\hline He is not whole without a soul to wait upon & مش موجود بلا ما سيد يئولو هات \\
\hline You walked in and oops- adaisy & دخلتي بدلتي الحالة \\
\hline While the cups do their soft shoeing & على ماو لادي عددهم يكمل \\
\hline Screw your courage to the stinking place & فين شجاعتكم وحشيتكم فين \\
\hline Shh! Trust me pet & هس يا بت \\
\hline $\begin{array}{l}\text { Let your power shine } \\
\text { Make the clock reverse }\end{array}$ & خلي الئوة تبان \\
\hline $\begin{array}{l}\text { Now she's here shinning in the starlight } \\
\text { If she's here it's crystal clear }\end{array}$ & وياهاو معاهأ و طريئي مش ميني محهول \\
\hline And I know one day romance will reign supreme & من المؤكد بوم حبئعانشئ أصبل \\
\hline I just want to see the floating lanterns gleam & أنا نفسي اشوف ف السمائناديل \\
\hline You think you own whatever land you land on & فاكر الأرض الي عليها ملككا \\
\hline we'll see them dying in the dust & لازم نحرء الزبالة دول \\
\hline $\begin{array}{l}\text { There's silver rivers flow } \\
\text { And gold you pick right off a tree }\end{array}$ & |أنها||ارمرجا||ان \\
\hline $\begin{array}{l}\text { Great Spirit, hear our song } \\
\text { Help us keep the ancient way } \\
\text { Keep the sacred fire strong } \\
\text { Walk in balance all our days }\end{array}$ & 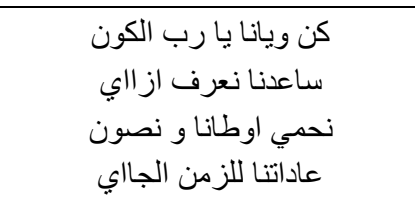 \\
\hline Seasons go and seasons come & 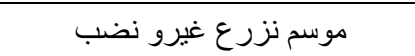 \\
\hline
\end{tabular}


The two metaphors that are analyzed in this section are: 'we'll see them dying in the dust' from 'Pocahontas' and 'he is not whole without a soul to wait upon' from 'Beauty and the Beast.' The following discussion shows how the connotations of the vehicles (dust and soul) are translated and manifests, whether reducing a metaphor into its sense causes loss or not.

The Image Metaphor 'Dying in the Dust'

'We'll see them dying in the dust' is a verse from the song 'Savages.' This song reveals the conflict between the Englishmen (white) and Native Americans (red). Each party threatens to get rid of the other. If the Native Americans just said 'we'll see them dying,' the intended meaning (that they want to kill the English) would be reflected. In this song, however, the metaphorical phrase 'in the dust' is used to imply further connotations; the image of death is compared to a thing that goes in the dust without being realized. The three parts of this metaphor are the object (death), the vehicle (dust), and the sense (being unworthy).

The Connotations of 'Dust'

A part of the overall meaning of this metaphor comes from its allusive meaning, which is "an inter-textual feature" and evokes "an associated saying or quotation" (Dickens et al., 2002:70). This metaphor is associated with: an idiom, 'bite the dust' and an event in the 1930s and is known as 'the dust bowl'.

'Bite the dust'- as explained by idioms.thefreedictionary, means to die, to break, to fail, to give out, and to stop existing. Thus, 'dying in the dust' connotes failing, breaking, and giving out as well as dying ("Bite the dust", 2020). These connotations imply that the Englishmen deserve death because they are an unworthy failing race. Their death is not realized like something that disappears in the dust.

On the other hand, this metaphorical expression reminds the readers of the dust bowl in the 1930s when dust storms destroyed the lands of the US and Canada. Because of this, thousands of people left their homes. This dust bowl caused death to land and human. In this context, the dust connotes a disaster or catastrophe that will happen and, as a result, so many people will die.

All these connotations, death, being unworthy, failing, catastrophe, and non- existing are expressed by this image metaphor. The image of these people turning into dust after they die is the intended sense of this metaphor. Nothing remains except this dust and their bones.

\section{Loss in Translating this Cultural Metaphor}

This metaphor translates as: 'لازمنحرء الزبالةدول' Does this expression have the same meaning and connotations the SM has? In the TM, Native Americans talk about Englishmen and describe them as being rubbish that has to be burnt. However, the referent to the 'dust bowl' is not reflected in Arabic, but is it crucial in this context? The audience is young teenagers, so they are not aware of the dust bowl; it is not of high importance in the translation; nevertheless, the connotations aroused by the allusions of 'dying in the dust' are expressed by' which means that these people are unworthy, so Indians have to get rid of them. 'نحرء' implies that there is a catastrophe that will take place and cause death to the Englishmen. The allusions of 'dust' are compensated by the use of a culture-free word 'نحرء' 'نبالة' and a verb.' Compensating allusions of a word by connotations of another word is CIK.

If the SM and TM are analyzed grammatically, the following will be noticed: 'We will see them dying in the dust' is a sentence whose complement is an adjectival phrase, which is the metaphor being studied. In this sentence, the singer is not the killer; he just watches while the Englishmen are dying; however, in 'لازم نحرء الزبالة دول', the singer is directly the killer. The implicit meaning intended in the original sentence transferred into an explicit meaning in the Arabic song. The class shift is the adjustment technique the translator uses to compensate the intended sense.

\section{The Metaphor' Without a Soul to Wait Upon'}

'He is not whole without a soul to wait upon' is a verse from the song 'Be Our Guest.' In this song, the kitchen tools compare their status in the old days with their condition now.

Table 5: A stanza from the song 'Be Our Guest' and its dubbing into the ED

\begin{tabular}{|c|c|}
\hline SS & DTS \\
\hline Life is so unnerving & 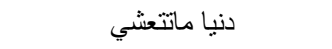 \\
\hline For a servant who's not serving & ل ل ل لخادم الي ما يخدمش \\
\hline He's not whole without a soul to wait upon & مش موجود بلا ما سيد يئولو هات \\
\hline Ah, those good old days when we were useful & اه على زمان كان لينا فايدة \\
\hline Suddenly those good old days are gone & فجاة راح زمان بئزكريات \\
\hline Ten years we've been rusting & عشر سنين بنصدي \\
\hline Needing so much more than dusting & جسمنا بتر اب متغطي \\
\hline
\end{tabular}


There are two metaphors embedded in this single metaphor. First of all, the candlestick is talking about the kitchen tools as being human beings; it uses some of the humans' attributes, such as waiting and the pronoun he, to refer to one of the tools. There is personification in this metaphor. The parts of this metaphor are: the object (the kitchen tool), the vehicles (he/waiting), the sense (the human being who waits on his master); the kitchen tools are likened to servants in this personification. In this animation film, the tools are the servants of the prince. The witch turned this prince into a beast and his servants into kitchen tools.

The similarity between the kitchen tools and servants is as follows:

$>$ Kitchen tools are used to present food and drinks to people. Servants serve people by using these kitchen tools.

$>$ Kitchen tools do not behave by themselves; they wait others to use them. Like the kitchen tools, servants do not behave as they want; their masters tell them what to do.

$>$ If there is no person in the house to use these tools, these tools become un-useful. If there is no master in the house, servants become without work, too.

$>$ When one of the kitchen tools becomes out of use, it is thrown away or broken; the same happens to the servant who can not serve his/her master.

Comparing a master to a soul is, furthermore, the second metaphor 'without a soul to wait upon.' The object is (the master), the vehicle is the (soul), and the sense is (being a kind person who deals with others as if they are not inferiors to him). The emotional connotations of the word 'soul' and the use of the verb 'wait' instead of 'serve' imply the kind of relationship between the master and his servants. They are dealing with each other soul to soul. 'Wait' implies that the servants (the tools) feel happy while they are serving their master; they even wait for this moment to come.

When this metaphor is translated into another language, the translator has to keep the connotations expressed by the original metaphor (the tools as servants and the master whom the tools serve happily as a soul). Whether there is a loss in the Arabic translation or not, and how the loss is handled are the issues demonstrated in the following sections.

\section{'مش موجود بلا ما سيد يئولو هات'}

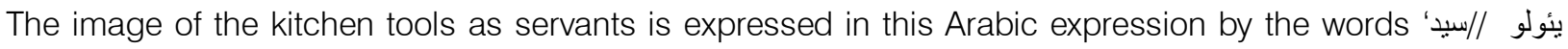
هات '. The personification that is reflected by the verb 'wait' and the pronoun 'he' in the SM is expressed by two verbs 'يئولو هات' in the translation.

The sense that the servants are not forced to serve is lost in using the imperative verb 'هوجرت ' But this sense is compensated in saying ' مش موجود, which implies that if the tools are not serving, they do not exist. The connotation of the verb 'wait' is compensated by using the phrase 'مش موجدود' This is another instance of CIK.

Moreover, there is a difference in the connotations expressed by the SM and its translation. 'He is not whole' translates as 'مش موجود.' 'Not whole' means that he exists but he is not complete. 'موجود,مش' 'on the contrary, means that he does not exist. 'Soul' translates into 'سيد' 'Soul,' as defined by the al-maany dictionary, means "innermost feelings, heart, spirit, one's self" ("Soul”, 2020). 'سيد' means "independent, master, chief, feudal lord, monsieur, and gentleman" ("سيد", 2020).

'Soul' does not have any meaning that connotes or denotes being a master, but from the context, the reader can get this meaning. The word servant is mentioned in the line that precedes this metaphor 'for a servant who is not serving,' and logically, if there is a servant, there is a master. The meaning is compensated in another place.

On the other hand, the emotional connotations of the word 'soul' are not reflected by 'سيد'. However, one of the meanings of 'سيد' is 'gentleman.' Being a gentleman means dealing with others gently. The audience deduce that this 'will not be bad in dealing with his servants. The connotations of 'soul' are compensated by the meanings of 'سيد'. This is another instance of CIK.

In other words, these two words can replace each other even if the Arabic word 'wي' is more general than the specific English term 'soul.' The gain that the Arabic version has is making it clearer for the young audience who may be puzzled by the use of soul. CIP and CIK protect the dubbed song from loss. The overall meaning of the SM is preserved.

\section{Preserving Sound Patterns}

There is a rhyme between the words 'upon' and 'gone.' The connection between the phrasal verb 'wait upon' and 'gone' implies that the soul which the tools wait has gone. They are out of service now.

In the translation, the rhyme connects between the words 'هاتو زكريات'; it implies that the tools are remembering the old days when the master asked them to do things, but these days the tools are out of service. The same rhyme is kept, and the sense reflected by this rhyme is preserved in the translation.

On the other hand, there is alliteration in the SM between the words: 'without and wait.' This alliteration phonetically and semantically connects these words; it implies that without waiting for a master, nothing is going to 
happen. In the Arabic dubbed song, there is alliteration in 'موجود' 'ماسيد و مش ' This alliteration means that if there is not a master, nothing exists. Again, the function employed by the alliteration in English is reflected in the translation.

c) Literal Translation

Table 6: Metaphors translated literally

\begin{tabular}{|c|c|}
\hline SMs & TMs \\
\hline Know that soon you'd want to leave the nest & عايزة أسيب العش أصل زهئت \\
\hline $\begin{array}{c}\text { Ask the dishes } \\
\text { They can sing } \\
\text { They can dance }\end{array}$ & 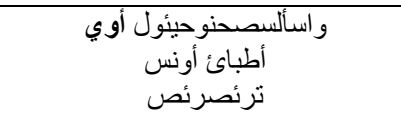 \\
\hline Dinning room proudly presents, your dinner & على ما أوضة السفرة تثندم بفخر عشاكي \\
\hline Suddenly those good old days are gone & فجأة راح زمان بئزكريات \\
\hline It's a nightmare but it's one exciting ride & ده كابوس لكن صيد و مطاردة جنان \\
\hline $\begin{array}{l}\text { Sweep up the years } \\
\text { Of sadness and tears } \\
\text { And throw them away! }\end{array}$ & و ودمو وارو السنين \\
\hline Men with pointy teeth, and & ناس ليهم أنياب \\
\hline Please, they'll eat you up alive & وحوش تاكللكفمفيش \\
\hline $\begin{array}{l}\text { Or asked the grinning bobcat why he grinned? } \\
\text { Can you sing with all the voices of the mountains? } \\
\text { Can you paint with all the colors of the wind? }\end{array}$ & و تقدر تغني بصوت القط البري بيضال تقدر ليه؟ \\
\hline
\end{tabular}

Translators, as stated by Newmark (1988), can resort to literal translation when the TL meaning corresponds with the SL meaning in terms of the referent and pragmatic effects. However, Newmark asserts that when a translator faces a translation problem, the literal translation strategy will be out of the question. If this is true, this translation procedure will be the last resort in translating metaphors in animation songs, but the translation of the metaphors in table (6) proves the opposite. The literal translation strategy can be one of the best translation strategies to deal with metaphors in animation songs. Both meaning and sound patterns are preserved.

In some instances where literal translation is used, the translator is obliged to add a word or phrase to the verse to preserve the rhyme of the song. However, such words do not affect the meaning, as they can be considered empty words, such as مفِّ in translating the metaphor 'they'll eat you up alive' into 'وحوش تاكلاك فمفيش.'The ward مفيش wis added to preserve the rhyme with مفيش .متعمريش does not affect the meaning nor the syllable count of the verse.

\section{Conclusion}

In animation songs, metaphors were translatable; both form and meaning can be approximated by using CIK and CIP. Metaphors are not only translatable; instances of gain were also found.

In animation songs, keeping the metaphoricity is not a priority as it is in other literary texts. What matters in translating metaphors in animation songs were: the meaning of the metaphor and its sound patterns.

There are three main strategies to translate metaphors in animation songs: 1) substitution, 2) paraphrasing, and 3) literal translation. Cultural equivalence, partial equivalence, functional equivalence are the procedures used in handling metaphors in the dubbing of animation songs.

Translators of animation songs have to be well-informed linguists, culturally-experienced translators, and musically talented people.

\section{ReCOMmendations}

The researcher recommends the following:

- More extensive studies on translating metaphors in dubbed songs has to be encouraged.

- The combination of dubbing song and metaphor translation theories has to be under the microscope of translation researchers.

- More researches have to be done in this field of study to tackle this issue thoroughly.

\section{References Références Referencias}

1. Barcelona, A. (2000). Metaphor and metonymy at the crossroads: A cognitive perspective. Germany: Die Deutsche Bibliothek. 
2. Broeck, R. V. (1985). The limits of translatability exemplified by metaphor translation. Poetics Today, 2(4), pp. 73-87. Retrieved on 5 January, 2014 from http://www.jstor.org/stable/1772487

3. Dickens, J., Hervey, S. \& Higgins, I. (2002). Thinking Arabic Translation: A course in Translation Method: Arabic to English. USA and Canada: Routledge.

4. Farghal, M. (1995). 'Lexical and discourseal problems in English-Arabic translation. Translations' Journal, 40(1), pp. 54-61 retrieved on 23 Dec, 2013 from http:// id.erudite.org/iderudite/002722ar

5. Luthen, H. W. (ed.). (2002). Surviving through the days: translations of native Californian stories and songs, a California Indian reader. London, England: Regents of the University of California.

6. Newmark, P. (1988). A Text Book of Translation. Great Britain: Prentice Hall International.

7. Park, O. (2009). The issue of metaphor in literary translation: Focusing on the analysis of a short story translation. Journal of Language and Translation, 10(1), pp. 155-157. Retrieved on 5 Jan, 2014 from http://scholar.google. $\mathrm{com} / \mathrm{scholar} ? \mathrm{hl}=\mathrm{en} \& \mathrm{q}=$ The + issue + of + metaphor $+\mathrm{in}+$ literary + translation\% $3 \mathrm{~A}+$ Focusing + on + the + analysis + of $+\mathrm{a}+$ short + story + translation\&btnG $=\& a s \_s d t=1 \% 2 C 5 \& a s \_s d t p=$

\section{Online Dictionaries}

8. Bite the dust. 2020. In the free dictionary. Retrieved from http://www.thefreedictionary.com/bite+the+dust.

9. Curdle. 2020. In al-maany dictionary. Retrieved from http://www.almaany.com/home.php?language= arabic\&word $=$ curdle\&lang_name $=$ English\&type_word $=0 \& d s p l=0$.

10. Soul. 2020. In al-maany dictionary. Retrieved from http://www.almaany.com/home.php?language=arabic\&word $=$ soul\&lang name $=$ English\&type word $=0 \& d s p l=0$.

11. 2020. In al-maany dictionary. Retrieved from http://www.almaany.com/home.php?language=arabic\&word $=\% \mathrm{D} 8 \% \mathrm{~B} 3 \% \mathrm{D} 9 \% 8 \mathrm{~A} \% \mathrm{D} 8 \% \mathrm{AF} \&$ lang_name $=$ English\&type_word $=0 \& \mathrm{dspl}=0$. 